\title{
“Oil Injustice” in Nigeria's Niger Delta Region: A Call for Responsive Governance
}

\author{
Theodore Okonkwo, Uzuazo Etemire \\ Department of Public Law, Faculty of Law, University of Port Harcourt, Port Harcourt, Nigeria \\ Email: theodore.okonkwo@uniport.edu.ng, uzuazo.etemire@uniport.edu.ng
}

How to cite this paper: Okonkwo, T. and Etemire, U. (2017) "Oil Injustice" in Nigeria's Niger Delta Region: A Call for Responsive Governance. Journal of Environmental Protection, 8, 42-60. http://dx.doi.org/10.4236/jep.2017.81005

Received: December 16, 2016

Accepted: January 19, 2017

Published: January 22, 2017

Copyright $\odot 2017$ by authors and Scientific Research Publishing Inc. This work is licensed under the Creative Commons Attribution International License (CC BY 4.0).

http://creativecommons.org/licenses/by/4.0/

\begin{abstract}
The injustice and chaos in the Niger Delta region of Nigeria resulting from the manner in which the oil industry is being run and regulated have since captured the attention of the world. Importantly, the 2011 UNEP Report on the Environmental Assessment of Ogoniland (a Niger Delta community) which revealed shocking levels of ecological degradation has helped to keep the issue on the front burners of international discussion. In this light, this article explores the nature of injustice in the oil producing areas of Nigeria; it assesses the regulatory mechanisms that have been set up to prevent and reverse the injustice in the region; and based on the inadequacies of the present system, it makes recommendations as to how the mechanisms might be better strengthened, and governance executed, all in a manner that is more responsive to the plight of the affected people.
\end{abstract}

\section{Keywords}

Oil and Gas, Petroleum, Injustice, Environmental Degradation,

Environmental Protection, Benefit Sharing, Niger Delta, Nigeria

\section{Introduction}

To begin, a few words describing the Niger Delta region of the Federal Republic of Nigeria-which is the geographical focus of this paper-are appropriate. The Niger Delta region of Nigeria lies between latitudes $4^{\circ}$ and $6^{\circ}$ north of the Equator and $4^{\circ}$ and $8^{\circ}$ east of the Greenwich. It is made up of the states of Akwa Ibom, Cross River, Edo, Imo, Rivers, Bayelsa, Delta, Abia and Ondo, making it coterminous with all of Nigeria's major oil producing states. Covering an area of over $70,000 \mathrm{~km}^{2}$ of the litoral fringes of the country, it constitutes the largest river delta in Africa and the third largest in the world, and is one of the world's most extensive mangrove forest regions [1].

Characterized by its distinct aquatic environment manifesting in diverse for- 
$\mathrm{ms}$, it is also known for its flat and fertile land mass. Little wonder the major occupation of the inhabitants of the region includes farming, fishing and hunting. In addition, the Niger Delta region habours over 35 billion barrels of proven crude oil reserve-which has been the subject of exploration and exploitation since the 1950s-and an even larger deposit of natural gas. Importantly, oil provides about $75 \%$ of Nigerian governments' revenue and $90 \%$ of its foreign exchange earnings [2].

Thus, the crude oil which comes from the Niger Delta region remains the mainstay of the Nigerian economy. Considering this fact, one would expect that the resident indigenes of the region should be highly regarded, fairly and equitably treated, as well as protected in relation to the output and effects of the oilrelated activities in their communities by the stakeholders in the oil industry, especially the Nigerian government. But, over the years, this has not been the case. Although, in a way, they "pay the piper", they are hardly given the opportunity to "see or touch the flute" let alone "dictate the tune"; they are "the goose that lays the golden egg"; yet have hardly partaken of it to a reasonable extent.

In other words, rather than care and reward, they have arguably been the recipients of unjust treatment on two levels at least-the physical level and the fiscal level. On the physical level, so to say, the oil industry, with the complicity of the government and without a viable and effective means of remedy, has been a source of massive environmental degradation and pollution in the Niger Delta, which condition has taken its toll on the socio-economic wellbeing of the people, particularly diminishing their health and means of livelihood, among others. And on the fiscal level, the financial benefits accruing from the exploitation of oil in their communities are arguably not being shared with them (whether directly, or indirectly in terms of the execution of developmental projects) in a reasonable and equitable manner.

As this injustice became unbearable, community agitation for solutions increased; first, peacefully, then violently when they could not otherwise get the attention of oil companies and the government [3]. The government responded by militarizing the region. Strands of the region's agitation metamorphosed into militancy and insurgency of various shades, "with differing goals and objectives ranging from nationalism and freedom fighting to outright criminality and terrorism" [2]. Hence, the Niger Delta become a hotbed for frequent protests, violent conflicts and outright criminality, all serving to increase the plight of people therein.

In light of the above, this article ultimately focuses on how best justice might be progressively achieved for the people of the Niger Delta whose home constitutes the "engine room" of the Nigerian economy. In this connection, the paper will first address the nature of the injustice suffered by the Niger Delta people. It will then assess generally the status of government efforts aimed at addressing this injustice. In view of the shortcoming in current efforts, proposals will then be made on how best governance may be made more responsive and relevant to the plight of these people and in helping to reasonably achieve justice for them. 


\section{Oil Injustice}

There are general laws in place which set standards that are relevant for ensuring that natural resource-bearing communities are humanely, fairly and justly treated in the event of commercial exploitation of the resources in their communities. At the minimum, laws relevant to Nigeria, particularly the African Charter on Human and Peoples' Rights [4] (African Charter) which has been properly domesticated in Nigeria via the African Charter on Human and Peoples' Rights (Ratification and Enforcement) Act [5] guarantees in Article 24 the right of all peoples to a "generally satisfactory environment favourable to their development". Its Articles 21 (on the right to natural resources) and 22 (on the right to development) establish the right of communities to an equitable share of the benefits emanating from natural resource exploitation in their communities $^{1}$; and this point was clearly made and applied in the 2010 decision of the African Commission on Human and Peoples' Rights' in the case of Centre for Minority Rights Development (Kenya) v. Kenya [6]. In addition, there is the right to "enjoy the best attainable state of physical and mental health" provided for in Article 16(1) of the African Charter.

Yet, as hinted above, the injustice to the people of the Niger Delta as it related to oil exploration and exploitation manifests on the two aforementioned levels (which indicates non-compliance at best, and disregard at worse, of the above rights and obligations): first, with respect to the sharing of benefits emanating from oil production, and second, as it relates to the degradation of the environment and its consequences for personal health and means of livelihood. These will now be considered below.

\subsection{Environmental Degradation \& the Underdevelopment Consequences}

Before the commencement of oil production in commercial quantity in the Niger Delta, the region was essentially an unspoiled environment which supported substantial natural resources for the resident population. Demonstrating the richness of the Niger Delta environment pre-oil production, writers have indicated that the environment,

Included among other things, medicinal herbs and barks, fish and shrimp, crabs and clams, wood for energy and shelter, as well as a stable soil for farming and habitat for exotic wildlife. There was the Delta elephant, the white crested monkey, the river hippopotamus, as well as a colorful array of exotic birds, crocodiles, turtles and alligators. The region also accounted for a large percentage of Nigeria's commercial fisheries industry [2].

\footnotetext{
${ }^{1}$ In addition, the 2014 African Charter on the Values and Principles of Decentralisation, Local Governance and Local Development also obliges states in its Article 4(b) to adopt national legislation and mechanisms to ensure that "local communities" equitably "benefit from natural resources exploited in their communities". This Charter was by the Twenty-third Ordinary Session of the Assembly, held in Malabo, Equatorial Guinea, 27th June 2014; available at: http://www.au.int/en/sites/default/files/treaties/7802-treaty-0049_-_african_charter_on_the_values_ and_principles_of_decentralisation_local_governance_and_local_development_e.pdf. Although the signatories to the Charter are increasing, the regime is yet to come into force.
} 
Ironically however, oil exploration activities which started in 1956 in Oloibiri town in the Niger Delta have since become the greatest cause of underdevelopment and environmental degradation in the region. This is so given that oil production activities in the region are executed in an unsustainable manner and largely without the best available technology-with the complacency and complicity of the Nigerian government that holds major shares in its various joint ventures with the major multinational oil producing companies. Thus, the operations have resulted, among others, in extensive gas flaring and massive oil spills which have devastated water bodies and forests, caused serious land pollution and loss of biodiversity, given rise to persistent noise pollution (form seismographic blasts which affect the integrity of buildings, roads and other physical structures) and light pollution (from glass flaring), as well as air pollution resulting in high occurrences of acid rain in the region [6].

As expected and well documented, this massive environmental pollution has produced severe health problems, e.g. a high level of respiratory infects and skin diseases, to mention as few, among the residents of the region; frequently devastating fishing and farming grounds as well as forests, it has also hugely affected in a negative way their meanings of livelihood as their main occupations are usually fishing, farming and hunting, thus, further driving them into poverty [7]. Further compounding the unjust treatment of the people in this region, in the event of such environmental pollution, if at all, there is hardly a reasonably attempt to rectify the damages done to the environment, health and socio-economic well-being of the people, or even compensate (adequately) the affected people and communities [2].

The scale of the above issues is exemplified by, and can be better appreciated in the state of the environment in Ogoniland (a Niger Delta community situated in Rivers State, Nigeria) as captured in the popular 2011 UN Environmental Programme (UNEP) Report on the Environmental Assessment of Ogoniland [8] with sufficient and shocking particularity. At one site in Eleme Local Government Area "the study found heavy contamination present 40 years after an oil spill occurred" [8], at another site " $8 \mathrm{~cm}$ layer of refined oil was observed floating on the groundwater which serves the community wells" [8]. On the loss of means of livelihood, it was found that "[w]here a number of entrepreneurs had set up fishing farms in or close to the creeks, their businesses have been ruined by an ever-present layer of floating oil" [8]. As a public health emergency, "community members at Nisisioken Ogale are drinking water from wells that is contaminated with benzene... at levels over 900 times above the [WHO] guideline" [8]; some well samples were found to be "at least 1000 times higher than the $\mathrm{Ni}$ gerian drinking water standard of $3 \mu \mathrm{g} / \mathrm{l}$ " [8].

Putting scenarios like these together, and absent other parts of the Niger Delta which are severely polluted as well, UNEP concluded that "the environmental restoration of Ogoniland could prove to be the world's most wide-ranging and long term oil clean-up exercise ever undertaken", and will actually take "25 - 30 years" to be completed [8]. 


\subsection{Inequity in Benefit Sharing}

In some other climes, it is a thing of joy for communities when natural resources like oil and gas are discovered in their terrain considering their developmental potentials for such communities. Thus, it was not out of place that the discover of oil engendered hope in Niger Delta communities that modern infrastructure such as electricity, pipe-borne water, educational facilities, well-equipped hospitals, tarred roads linking communities with the rest of the country, and more, will become available [2]. Also, expectations were high that oil companies would take seriously the ideals of corporate social responsibility, and that people from oil producing communities would progressively have the opportunity of gainful employment. However, these expectations of oil-bearing communities sharing reasonably in the benefits from petroleum production have largely been dashed by the oil companies and the government over the years.

Indeed, the distribution of benefits from petroleum production has been widely held to be inequitably against the interest and development of the oil producing areas. It has been noted in a report that:

Today, the inhabitants of this village/community [Oloibiri, where oil was first discovered in Nigeria in commercial quantity] are left with nothing but damaged farmlands and polluted rivers with no electricity, potable drinking water and other basic social amenities. Like the Oloibiri situation, the locals in many of the oil-bearing communities claim to still live in primitive conditions akin to that of the Stone Age, side by side with the high tech and modern facilities of the multinational community that they play host to [9].

Although crude oil is the mainstay of the Nigerian economy, oil producing communities have received little or no benefit in terms of development, compared with the burden they bear from oil production activities in their communities and the benefits other stakeholder in the industry derive therefrom [10]. They have watched as resources from their communities have been taken and used to develop many other communities in the country that do not comparatively suffer the negative effects of oil production. Even within their communities, they see how oil companies provide state-of-the-art facilities for the comfort of their employees, while they are left with a degraded environment and standard of living.

The level of injustice to the oil producing region is further reflected when one recalls the period before oil become the main source of revenue for the country. At a time, it is on record that revenue sharing was based on a formula of " $50 \%$ equality and 50\% derivation"; this was when "groundnut, cocoa and palm oil from the three major groups in the country-namely: Hausa, Yoruba and Ibowere the major source of revenue in the country" [11]. But when oil became the mainstay of the country's economy and agricultural production in the country went down drastically, this sharing formula was jettisoned in favour of figures far less favourable to the oil producing areas.

In fact, according to the 2002 Ogomudia Report, "[b]efore the civil war, the 
Principle of Derivation was $100 \%$; during the civil war, it dropped to $50 \%$ and subsequently $0 \%$ "; and since the end of the civil war, "it has at different times been $0 \%, 1.5 \%, 3 \%$ " [12] which were all highly inconsequential figures for the development of the region. And this was despite the fact that the various Constitutional Conferences held even before the independence of Nigeria clearly recognized that the Niger Delta was (and still remains) an area for "special development initiative" and attention given "the difficult terrain" [12].

Add this level of inequity in benefit sharing from the oil industry to the environmental degradation and its consequences in the region and what you have, among other societal ills, are the violent conflicts and militancy that have come to characterize the region. Noting that "[d]issatisfaction with financial benefits accruing to residents led to increasingly strident agitations, constant violence, and kidnapping [in the region]", Omorogbe trumpets the yearnings of the people that, to a large extent, exudes fairness and equity in the management and sharing of benefits from petroleum production, thus:

In agitating for a change in the distribution of financial resources from petroleum production, the term "resource control" [footnote deleted] has emerged. It is an umbrella term symbolizing what is seen as a struggle for equity and justice in the Niger Delta... It is linked to desires, aspirations and activities directed towards greater control and increased wealth over petroleum resources derived from the production area. For some, "resource control" is about ensuring that primary responsibility for decision-making rests in the areas where petroleum is produced, or ensuring that the area of production gets the bulk of the revenues-for which the term "fiscal federalism" is used [13].

\section{Regulatory Systems to Prevent and Reverse Environmental Degradation and Its Effects- What More Needs to Be Done?}

Having set out and clarified above the environmental injustice and its further effects on oil producing communities, this section $\mathrm{x}$-trays the regulatory system and efforts that have been put in place to help prevent and reverse these negative effects of petroleum production.

\subsection{Legislative Measures}

There are legislation and legal instruments aimed at preventing as well as reversing environmental pollution from oil and gas activities whenever they occur. Unfortunately, in Nigeria, environmental legal instruments in this regard are largely inadequate, especially in terms of their coverage and quality; and this is in line with the UNEP's allusion to the fact that a major reason (but not the only one) why developing nations like Nigeria have largely failed in the area of ensuring environmental protection has to do with "lack of adequate legislation" [14].

Take for example the Environmental Impact Assessment (EIA) Decree No. 86 
of 1992 which is now the EIA Act [15]. This Act, which was partly enacted in response to agitations in the Niger Delta as regards environmental pollution and media and international pressure on the government and oil companies at the time [3], aims, like every other EIA measure, to mainstream environmentrelated considerations into development projects. So as to effectively achieve this aim, it is internationally accepted as a general principle that "[p]ublic participation is a fundamental component of the environmental impact assessment (EIA) process" [16]. Yet, among other aspects, it is in this area of ensuring public participation in decision-making relating to a proposed project that the EIA Act is most inadequate and weak. It barely creates such a right or opportunity for the relevant communities in a meaningful way.

For instance, while Section 7 of the EIA Act provides that the public be given the opportunity to make comments on the EIA of a proposed activity before any final decisions can be taken by the responsible authority, Section 14(1) of the Act, contrary to international best practice, grants the relevant government authorities arbitrarily wide and largely unguarded powers to exclude the requirement for EIA for a given project (and therefore public participation in the process), which power they have frequently put to use to the detriment of the environment as attested to by many [17].

Thus, there is continued protest by those in the Niger Delta about the lack of their involvement in environment-related actives that affect them as engendered by weak and inequitable procedural laws and practices. In addition, research has also shown that the nearly 25-year old EIA Act-which is partly outdated not having been reviewed, updated or amended at all and contains weaknesses in substance reflective of its military roots-is seriously deficient in many other aspects compared to international best practice in the field, hence its inability to fulfill its aim in any reasonable measure [18].

Under the "Environment" section of the 2014 Nigerian National Conference Report, the review of the EIA Act was recommended, including the fact that not just "projects" (as is currently the case under the Act) but "all policies, plans and programmes be subjected to Strategic Environmental Assessment (SEA) in pursuance of environmental sustainability" [19]. In realization of its weaknesses and seemingly in compliance with the later recommendation, the federal government is currently finalizing a new, broader and more modern EIA law that will effectively serve to protect the environment [20]. It is only hoped that this process is sped up and concluded with the involvement and contribution of interested civil society members.

Even the Environmental Guidelines and Standards for the Petroleum Industry (EGASPIN) which was first issued by government authorities in 1992 (but reviewed subsequently in 2002) and majorly constitutes the operational basis for environmental regulation of the oil industry in Nigeria and also contained provisions for quick and proper cleanup by oil companies in cases of oil spill, is still inadequate in certain key aspects. For instance, UNEP has fingered the instrument as being "internally inconsistent with regard to one of the most important 
criteria for oil spill and contaminated sites management-specifically the criteria which trigger remediation or indicates its closure" [8]. Thus, little wonder that the UNEP study found in Ogoniland "heavy contamination present 40 years after an oil spill occurred" despite claims by the oil industry that the polluted site had been cleaned-up [8].

In addition, even though aspects of Nigerian environmental law relevant to the oil industry reasonably measures up with international standards, light and ineffective penalties and sanctions for their violation have "encouraged" oil companies to continue oil production in an unsustainable manner that violates the law, the environment and the people. For example, Regulation 25 of the 1969 Petroleum (Drilling and Production) Regulations [21] obliges oil producers to adopt all practical precautions to prevent, control and end environmental pollution where they occur, and Section 25 (1) (a) (iii) of the 1969 Petroleum Act [22] grants the Minister of Petroleum Resources the power to revoke an oil operator's license to operate in the event that the operator fails to comply with good oil field practice. However, "while some oil licenses and leases have been revoked, as far as Amnesty International could discern revocation has never been done on the grounds of environmental damage" [23]. Amnesty International has also rightly noted that:

The penalties for pollution and environmental damage are frequently financial and relatively low. For example, the fine for failing to report an oil spill to NOSDRA is 500,000 naira... The fine for failure to clean up the impacted site "to all practical extent, including remediation" incurs a fine of one million naira... These fines are inadequate to ensure compliance with the law and to prevent damaging practices [23].

The solution is not rocket science. Like every other country of the world where environmental protection is relatively well esteemed, those in the executive and the legislature in the country must build political will to address the dire environmental challenges of the Niger Delta and take the job for which they have been elected, appointed and paid, more seriously. They must: analyze current situations on ground; review, update and strengthen relevant law in line with international best practice; make new ones where necessary; and, together, diligently monitor and ensure their implementation and enforcement ${ }^{2}$. It is worth noting that, among others, the 2014 Nigerian National Conference Report reasonably recommended the Associated Gas Re-injection Act of 1979 [24] be amended to provide for stiffer and more prohibitive sanctions including fines for gas flaring, and for such fines to be "paid to the communities that are directly affected by such flaring rather than the Federal Government" [19].

\footnotetext{
${ }^{2}$ On the side, the Petroleum Industry Bill (PIB) which, in its original form as prepared, was widely considered as holding the potential to deliver, to a large extent, substantial justice to the Nigeria Delta people and wipe away their tears to a level. Yet, for years now, rather than pass the PIB into law, it is being unnecessarily tossed between the federal legislative houses and watered down. We can only hope and continue to advocate that Nigerian federal legislators see the need to side with oil producing communities who have sacrificed so much for the benefit of the nation with little or nothing to show for it.
} 


\subsection{Institutional Measures}

Related to the above discussion are issues that have to do with the institutions in place to help address issues of environmental degradation and its consequences. First, the judiciary stands out in this regard and, to an extent, have provided remedy to aggrieved community members in the Niger Delta in cases of oil spill and environmental pollution that have also gone on to affect their meanings of livelihood and endangered their health. For example, in cases like Shell Petroleum Development Company Nigeria Ltd v. Chief G.B.A. Tiebo \& Others [25] and ELF Nigeria limited v. Sillo \& Another [26] where environmental damage affecting members of communities was proved, the courts provided remedies and awarded damages to the plaintiffs against the oil companies responsible. Yet the efficacy of the Nigerian courts in this regard leaves much to be desired, especially in view of the political and socio-economic context of Nigeria.

Assessing the quality of access to courts in litigation relating to the oil industry in Nigeria, Frynas, a renowned scholar in the field, found on the basis of empirical research that: on the part of the litigants, the major constraints to access to justice through courts include high level of poverty as well as lack of education and information of their legal rights; and on the part of the courts, the major constrains include excessive delay in disposal of cases, inadequate judicial capacity in environmental cases, the application of archaic and restrictive locus standi rule which limits access in genuine cases of grievances, and the expensive and complex nature of court procedures [27] [28]. Hence, partly because people of the region find it difficult to access justice through the courts, taking the law into their hands becomes attractive.

A number of options are open to the authorities with respect to restructuring the judiciary and making it more responsive to the plights of those who suffer harm from environment pollution to such an extreme level: the idea of establishing dedicated environmental courts or environmental divisions with the existing court structure, together with simplified summary procedures, should certainly be explored to speed up and give prompt attention to environmental cases; court filing fees could be reduced and the Legal Aid Scheme enhanced to effectively cover cases involving litigants from poor affected communities which are usually in the rural areas and lack the financial muscle to finance litigation against the much richer oil companies; allowance for public interest litigation should be made, and the current restrictive standing rule set aside either by legislation or by broad and innovative interpretations by the courts; capacity development among judicial officers as it relates to environmental case is vital; and lastly, effort should be made to increase awareness and resort to generally more cost-effective and similar alternative dispute resolution mechanisms-like arbitration and others-which are largely in tandem with the traditional mode of dispute settlement in African societies [29].

Apart from the courts, there are other federal government executive institutions with the responsibility of regulating the activities of oil companies and en- 
suring environmental protection as it relates to the oil and gas industry. However, the reality is that the regulations imposed on the oil industry are not adequately enforced due to lack of independent oversight by relevant environmental agencies. As the oil industry is comprised of joint ventures between the Nigerian government (usually as the major stakeholder) and the multinational oil companies like Shell, the relevant agencies have been unable to effectively play their role as regulator in relation to these entities; in such a situation "independent regulatory agencies and oversight are essential to avoid a conflict of interest" [30]. Even as between government agencies, how can the Department of Petroleum Resources (DPR), which has some responsibility to regulate oil pollution, effectively do this when it is in alignment with the Ministry responsible for oil production [30]?

In addition, conflicting responsibilities and approaches between regulators weakens the regulatory system and the prospect for achieving effective environmental protection. For instance, according the UNEP Report on Ogoniland:

The study found that the [DPR] and the National Oil Spill Detection and Response Agency (NOSDRA) have different interpretations of EGASPIN. This is enabling the oil industry to close down the remediation process well before contamination has been eliminated and soil quality has been restored to achieve functionality for human, animal and plant life [8].

Importantly also, relevant regulatory agencies are plagued by inadequate human, financial and technological resources needed to effectively monitor oil companies and enforce environmental laws when violated. Again, the UNEP Report on Ogoniland exemplifies this point thus:

Nigerian government agencies concerned lack qualified technical experts and resources. In the five years since NOSDRA was established, so few resources have been allotted that the agency has no proactive capacity for oilspill detection. In planning their inspection visits to some oil spill sites, the regulatory authority is wholly reliant on the oil industry for logistical support [8].

Considering the above, if these organizations must function effectively in ensuring environmental protection in the region, the government must fund and equip them adequately. Legislative and administrative steps must also be taken to ensure that the responsibilities and approaches of regulatory agencies do not conflict, but complement one another. This much was also recommended in the National Conference Report under the section on "Environment" [19].

\section{Regulatory Systems to Ensure Equitable Sharing of Benefits-What More Needs to Be Done?}

Having set out and clarified above the injustice to the oil producing areas in the sharing of benefits from oil production in their communities, this section focuses on the regulatory mechanisms that have been put in place to address this particular injustice and ensure that the benefits are equitably shared. 


\subsection{Better Revenue Sharing Formula}

Firstly, as discussed above, at a time before oil became the mainstay of the country's economy, revenue sharing was based on a formula of $100 \%$ to $50 \%$ derivation. But when oil became the main source of revenue for the country, this formula that ensured substantial benefit to the main resource regions in the past was set aside in favour of a more reduced and inequitable scheme of $0 \%, 1.5 \%$, $3 \%$ at different times. After much protest and struggle by people in the region, the Niger Delta was granted 13\% derivation under the 1999 Nigerian Constitution (as amended). This current principle of derivation is encapsulated in Section 162(2) of the Constitution, thus:

The President, upon the receipt of advice from the Revenue Mobilisation Allocation and Fiscal Commission [RMAFC], shall table before the National Assembly proposals for revenue allocation from the Federation Account, and in determining the formula, the National Assembly shall take into account, the allocation principles especially those of population, equality of States, internal revenue generation, land mass, terrain as well as population density;

Provided that the principle of derivation shall be constantly reflected in any approved formula as being not less than thirteen per cent of the revenue accruing to the Federation Account directly from any natural resources.

Even though this current $13 \%$ derivation fell short of the expectation of the stakeholders in the Niger Delta, it was accepted as a reasonable start on the journey to achieving a more equitable benefit sharing formula in this regard. The fact that $13 \%$ was not an acceptable destination-whether from a historical perspective or in light of current realities and the uniquely difficult terrain of the region development-wise-was made clear in subsequent agitations and recommendations. For instance, the subsequent "National Political Reforms Conference recommended an increase of this percentage to $15 \%$ while the Joint Committee of the National Assembly proposed an increase to $18 \%$ in the Constitutional Amendment Bill", but these efforts have not been fruitful [11].

In agreement with the above, it is submitted that the $13 \%$ should be substantially increased to about $50 \%$ in accordance with the recommendation of the 2002 Ogomudia Report [12] in order for oil producing communities to share equitably in the benefits from the resource with which they have been blessed, and "to keep the tenor and vision behind the development of the Niger Delta alive through the veritable principle of derivation" [31]. This call is particular germane considering the falling price of oil at the international market. It is also an important call considering the fact that people of this region have not benefited in any reasonable measure from the exploitation of their traditionally owned oil resource since the commencement of commercial oil production in the region 60 years ago. The urgency is further heightened when one remembers that crude oil is a finite resource and that already there are various speculations that commercial production of oil and gas in the region can only last a few more 
decades [32] [33].

Moreover, the $13 \%$ derivation is overdue for upward review considering that the present economic realities are vastly different from what existed in 1999. To be sure, the Constitution envisages such upward review. Apart from the proviso of Section 162(2) which explicitly states that derivation be set at "not less than" $13 \%$, thus presupposing that the figure can be increased, Section 32(b) of Item F of the Third Schedule to the Constitution empowers the RMAFC to "review, from time to time, the revenue allocation formulae and principles in operation to ensure conformity with changing realities." (emphasis added). This has never been done; but it needs to be done as a matter of urgency.

Secondly, ensuring adequate and equitable benefit sharing of proceeds from oil production as it relates to oil-bearing communities extends beyond requests for "more money" to accountability for that which has so far been, and is being, released to the various Niger Delta states. While the request, for "more money" is justified in its own right, calls are increasingly being made, and rightly so, forrelevant state governments to show how they have spent what they have received so far, and to ensure that what is being collected at the moment is properly utilized. In fact, among many others, the actual situation of things is well captured in a 2012 report, thus:

Oil producing communities in six states of the federation have raised an alarm, alleging that their state governments have either misappropriated or misapplied a whoping N7.282 trillion, being payments of the 13 per cent derivation for 13 years, leaving the oil and gas communities in hunger and abject poverty... The state governments which received this money illegally use the fund to develop their state capitals and non oil and gas producing communities, leaving the actual oil and gas producing communities in hunger and penury [34].

The argument further put forth by oil producing communities, which is indeed reasonable, is that the $13 \%$ derivation is not part of the normal consolidated revenue due to Niger Delta state governments or any other tier of government from the federal government; "[i]t is standing on its own to the credit of the oil and gas producing communities as a first charge on the Federation Account", and its allocation to, and administration by, the state governments is not in accordance with the letter and spirit of Section 162(2) of the Constitution [35]. In other words-and rightly so-as it applied to the Niger Delta, the "13 per cent derivation fund is a benchmark for revenue allocation to the oil and gas producing communities of Nigeria and not for the state governments" to use in building new government houses and developing the state capital at the expense of the actual oil producing communities [35]. And the fact that this $13 \%$ revenue is not part of the states consolidated revenue from the federal government, but is mainly targeted at areas from where natural resources are derived for the benefit of the nation, must be reflected in the manner in which it is applied.

In support, it has been widely noted that the RMAFC agreed with the above 
view in its submission on a new revenue sharing formula to the $6^{\text {th }}$ National Assembly, stating that the $13 \%$ derivation was not part of the funds of any tier of government and should ordinarily not go to them [36]; whereupon the Chairman of RMAFC recommended via a bill (which was not passed) the creation of State Derivation Boards, possibly with the involvement of representatives from the relevant communities, to enable the oil producing communities have a more direct access to the funds [35]. This would have brought the situation closer to what existed when derivation was only $3 \%$, as it is reported that at that time the funds were "administered directly by the communities through their leaders and representatives" [35].

Thus, measures to bring about such a situation is certainly preferred and advocated for, as bringing the administration of the funds closer to the oil producing communities would potentially help speed up their development and address the inequities they have suffered for many years include the neglect by some of their own state governments. The establishment of the $13 \%$ derivation is largely due to the efforts and agitations of the oil producing communities, and no entity should be allowed to shortchange them with respect to benefiting from the funds.

\subsection{Establishment of Development Institutions}

To address the plights and injustice which the Niger Delta people has undergone, the Nigerian government has found it useful to create institutions that it believes will help achieve this purpose. It was to this end that the Ministry of Niger Delta Affairs was established in 2008 to "formulate and coordinate policies for the development and security of the Niger Delta region" [37]. Also, in 1992 the government of General Ibrahim Babangida established the Oil Mineral Producing Areas Development Commission (OMPADEC) as an interventionist agency that will help facilitate the development of oil producing areas-much like its predecessors: the Niger Delta Development Board established in 1961 and the subsequent Niger Delta Basin Development Authority put in place in 1976. Unfortunately, the operations of OMPADEC were hampered by inordinate political and other interests from the center and became an avenue for a few individuals to enrich themselves at the expense of the Niger Delta people [11]. This eventually led to its being scrapped.

The current Niger Delta Development Commission (NDDC) was established with a similar aim, as though a change of name and nomenclature is what was needed to make such an institution effective. While NDDC has made some efforts at achieving its aim, its story has not been much different from that of OMPADEC as it relates to mismanagement and corruption. Former president Jonathan while inaugurating a fresh Board for NDDC in December, 2013, hinted at the shoddy manner in which the body went about its mission of developing the region when he was reported to have stated that:

A body like NDDC should not just go into a voyage of contracts procurement but ongoing projects must be completed for people to benefit before 
new ones are awarded... There are just too many ongoing projects and we believe that you don't even have enough manpower to manage the ongoing projects [38].

The former president also alluded to financial impropriety by the previous management of the NDDC when, on the same occasion, he posited that:

If you aggregate the total amount of money the Federal Government has spent on this agency, (it) is enormous. And I don't believe on ground that we have something to show. The former board at a time had to be dissolved because instead of the board to work with the management to make sure that people from the area benefit from the NDDC, they were busy quarrelling over money [38].

More recently, there was a clash in a meeting between member of the House of Representatives Committee on the NDDC where certain top members where accused of influencing the unfair distribution of projects to be executed by the NDDC in favour of their communities and areas to the exclusion of others [39]. In the same meeting, vexed by the unfair and lopsided allocation of projects, one of the members noted that a particular project in the NDDC budget that was being defended was duplicated to the tune of 1.7 billion: "They did this road and the asphalt overlay; I have seen another 1.7 billion, it is for the same portion on the same road by another contractor", he revealed [39].

On the whole, indicating the failure of various government interventions (including the $13 \%$ derivation and the NDDC) in the Niger Delta, the Minister of States, Petroleum Resource, Dr Ibe Kachikwu in August 2016 openly stated that there was no development on ground to justify the over $\$ 40$ billion that have accrued to the region in the last 12 years alone from various sources. He said: "I've been to the creeks myself and discovered that there was no meaningful development of the riverine communities as expected by the federal government despite the huge amount disbursed to the region" [40]. In addition, even when funds are released, they are many times used to carry out "white elephant" projects which have little or no bearing or relevance to the major plight of the Niger Delta people.

Therefore, if these institutions must be retained, and if they would reasonably achieve the purposes for which they were set up, government must take serious measure to ensure transparency, accountability and probity in their activities. For instance, details of all contracts awarded by such institutions must be widely publicized through electronic and print media together with regular progress reports on their execution and financing, in order to allow for informed press and public scrutiny of their activities. Indeed, this will be in addition to the implementation of various provisions of the NDDC Act [41], such as Sections 19 and 20, that mandate the Commission to report quarterly to the President and annually to the National Assembly on its activities to ensure a critical appraisal of its effort. Yet, since its inception, the NDDC has to a large extent not complied with these obligations as Okogbule noted [11]. 
Also, to ensure that projects executed are those that meet the major needs of the people and are of priority to the affected Niger Delta communities, the government and NDDC must carry out a proper needs assessment of the particular oil producing community. For such to be successful, a bottom-top approach to development must be adopted "which entails the involvement and input of host communities in the selection of priority projects" [11] and where they should be located. This was also part of the directives given by the Presidential Monitoring Committee (PMC) on NDDC in its 9-point communique issued to the body, which also rightly: "advocated the sanctioning of erring contractors and consultants over sub-standard jobs and project abandonment"; "urged the NNDC to engage the services of competent and qualified contractors for project execution"; and "called on the NNDC to give priority to the completion of abandoned projects across the Niger Delta region" rather than awarding new contracts to the detriment of ongoing projects [42].

Beyond these issues, the 2014 Nigerian National Conference Report contains the following acceptable recommendation that will help oil producing communities participate better in the sharing of benefits from the industry:

The current divestment is bringing many indigenous operators into the sector. Accordingly, we feel that producing communities who can find the finance, and are sufficiently well organised can and should be given equity of at least $10 \%$ by the indigenous entities. For the communities to be overlooked by the government that has right of consent to these deals does not make good sense for business or security of facilities [19].

There is also the 2011 UNEP Report on Ogoniland which assesses the extent of ecological damage to Ogoniland by the oil industry and lays out the modalities for the eco-restoration of the damaged environment. Yet, the implementation of this report has been pending for years now. However, the Nigerian government is taking some steps in that direction as it launched its implementation on the $2^{\text {nd }}$ June, 2016, and inaugurated the Governing Council and Board of Trustees for the Implementation of the UNEP Report on Ogoniland on the $4^{\text {th }}$ of August, 2016 [43]. To main the political momentum, the government needs to moves quickly to the actual cleanup and eco-restoration stage, and explore ways of extending the same benefit to other affected communities, as soon as possible. Importantly, the following recommendation in the report should also be kept in view and taken seriously in order to ensure that the affected communities derive environmental and economic benefits from the cleanup and eco-restoration exercise: "Ogoni communities should take full advantage of the employment, skills development and other opportunities that will be created by the clean-up operation which is aimed to improve their living conditions and livelihood" [8].

\subsection{Amnesty Programme}

The high level of restiveness in the Niger Delta region, as alluded to earlier, is partly an offshoot of the injustice-both physical and fiscal-meted out on the region. The violence which also involved blowing up oil pipelines, led to in- 
creased environmental pollution in the region and a worsening of the economic plight of the people, especially as the atmosphere in the region became highly unwelcoming to investors. At a time, this instability in the region threatened both the national and international economic stability, and left Nigeria losing as high as $\$ 8.7$ billion $(\$ 54,375,000)$ in oil revenues per day as a result of the conflict [44]. It also became clear that military efforts in the region would, of course, not produce the desired result of sustainable peace and tranquility.

In that light, to stem this tide of environmental and economic loss, as well as create the enabling environment for the region to begin to witness some form of development, the federal government in 2009 granted amnesty-which came with vocational training opportunities and regular financial assistance and stipends-to members of many of the armed groups in the region that embraced the programme [45]. While this measure provided relative peace in the region for some time, it was clear to any discerning mind that the amnesty programme was not a sustainable solution to the problem of violence in the region [46], but only a temporary one to give the government and the oil companies just enough time to begin addressing the core issues of injustice in the region that led to such heightened violence in the first place.

In the region, not much changed after the grant of amnesty in terms of government's approach, and that of the oil companies, to the core issues of environmental protect and remediation, development and benefit sharing, as well as community access to environmental information and participation in decisionmaking processes concerning the exploitation of natural resources in their communities [47]. Thus, little wonder that the nation at the moment is witnessing a resurgence of militancy in the Niger Delta once again-considering the rise of the Niger Delta Avengers and other militant groups [48] — with a similar effect on the environment and the economy of the nation. While two wrongs do not make a right and militancy must be condemned as a means to achieving justice (because it only serves to worsen the situation), government must quickly begin to address the core issues of injustice in the Niger Delta as a way of sustainably checking the increasing violence and conflict in the region. There are no shortcuts to a sustainable solution in this regard.

\section{Conclusions}

We have so far discussed: the nature of injustice in the oil producing areas of Nigeria, mostly from an environmental and economic perspective; the regulatory mechanisms that have been set up to prevent and reverse such environmental degradation in the region and the lack of access to adequate share of the benefits derived from oil production in the relevant Niger Delta communities; and based on the inadequacies of the present system, recommendations have in the same breathe been made as to how the mechanisms may be further strengthened and governance executed in a manner that is more responsive to the plight of the affected people.

To drive this entire process and ensure the sustainable development of the oil 
producing communities in the Niger Delta, the political will of the Nigerian government and the willingness of the oil companies must be fanned to flame; and this where members of public and organized civil society come in-in helping to keep the pressure on the stakeholders in the oil industry for them to do the right things and be fair and just to the oil producing communities.

\section{References}

[1] Eyinla, P. and Ukpo, J. (2006) Nigeria: The Travesty of Oil and Gas Wealth. The Catholic Secretariat of Nigeria, Lagos.

[2] Afinotan, L.A. and Ojakorotu, V. (2009) The Niger Delta Crisis: Issues, Challenges and Prospects. African Journal of Political Science and International Relations, 3, 191.

[3] Adomokai, R. and Sheate, W.R. (2004) Community Participation and Environmental Decision-Making in the Niger Delta. Environmental Impact Assessment Review, 24, 495. https://doi.org/10.1016/j.eiar.2004.01.002

[4] 27 June 1981, 1520 UNTS 217.

[5] Cap A9 Laws of the Federation of Nigeria, 2004.

[6] Aaron, K.K. (2006) Human Rights Violation and Environmental Degradation in the Niger Delta. In: Porter, E. and Offord, B., Eds., Activating Human Rights, Peter Lang, Oxford, Barne and New York, 193-215.

[7] Opukri, C.O. (2008) Oil Induced Environmental Degradation and Internal Population Displacement in the Nigeria's Niger Delta. Journal of Sustainable Development in Africa, 10, 173.

[8] United Nations Environmental Programme (UNEP) (2011) Environmental Assessment of Ogoniland. UNEP Report.

[9] Oviasuyi, P.O. and Uwadiae, J. (2009) The Dilemma of Niger-Delta Region as Oil Producing States of Nigeria. Journal of Peace, Conflict and Development, 16, 110.

[10] Edu, K. (2011) A Review of the Existing Legal Regime on the Exploration of Oil and the Protection of the Environment in Nigeria. Commonwealth Law Bulleting, 37, 307. https://doi.org/10.1080/03050718.2011.572637

[11] Okogbule, N.S. (2007) The Plight of the Minority Niger Delta in Nigeria: The Poverty of Protective Legal and Institutional Mechanisms. University of Benin Law Journal, 10, 118.

[12] Ogomudia Report (2002) Report of the Special Security Committee on Oil Producing Area Vol. 1. Submitted to the President of the Federal Republic of Nigeria, Chief Olusegun Obasanjo, GCFR.

[13] Omorogbe, Y. (2016) Resource Control and Benefit Sharing in Nigeria. In: Barrera-Hernández, L., Barton, B., Godden, L. and Rønne, A., Eds., Sharing the Cost and Benefits of Energy and Resource Activity: Legal Change and Impact on Communities, Oxford University Press, Oxford, 259.

https://doi.org/10.1093/acprof:oso/9780198767954.003.0015

[14] Juras, A. (2012) The Bali Guidelines for Development of National Legislation on Access to Information, Public Participation and Access to Justice in Environmental matters. A Presentation at the 1st Meeting of Focal Points Appointed by Governments of the Signatory Countries of the Declaration on the Implementation of Principle 10, Held in Santiago de Chile. http://www.eclac.cl/rio20/noticias/paginas/8/48588/Alexander_Juras_English.pdf

[15] Cap E12 Laws of the Federation of Nigeria (2004). 
[16] Hartley, N. and Wood, C. (2005) Public Participation in Environmental Impact Assessment-Implementing the Aarhus Convention. Environmental Impact Assessment Review, 25, 319-340. https://doi.org/10.1016/j.eiar.2004.12.002

[17] Omorogbe, Y. (2002) The Legal Framework for Public Participation in DecisionMaking on Mining and Energy Development in Nigeria: Giving Voices to the Voiceless. In: Zillman, D.N., Lucas, A.R. and Pring, G., Eds., Human Rights in National Resource Development: Public Participation in the Sustainable Development of Mining and Energy Resource, Oxford University Press, Oxford, 549. https://doi.org/10.1093/acprof:oso/9780199253784.003.0015

[18] Etemire, U. (2015) Law and Practice on Public Participation in Environmental Matters: The Nigerian Example in Transnational Comparative Perspective. Routledge, London.

[19] The 2014 Nigerian National Conference Report.

[20] Njoku, J. and Olusupo, F. (2015) FG Commence Validation of Reviewed EIA Act 1992.

http://www.vanguardngr.com/2015/06/fg-commences-validation-of-reviewed-eia-a ct-1992/

[21] LN 69 of 1969.

[22] Cap P10 Laws of the Federation of Nigeria (2004).

[23] Amnesty International (2009) Nigeria: Petroleum, Pollution and Poverty in the Niger Delta. Amnesty International Publication, London.

[24] Cap A25 Laws of the Federation of Nigeria (2010).

[25] 9 Monthly Judgment of the Supreme Court 158 (2005).

[26] 6 Nigerian Weekly Law Report (Part 350) 258 (1994).

[27] Frynas J.G. (2001) Problems of Access to Courts in Nigeria: Results of a Survey of Legal Practitioners. Social and Legal Studies, 10, 397-419.

[28] Frynas, J.G. (2000) Oil in Nigeria: Conflict and Litigation between Oil Companies and Village Communities. LIT/Transaction, Hamburg.

[29] Okogbule, S. (2004/5) Access to Justice and Human Rights Protection in Nigeria: Problems and Prospects. Benin Journal of Public Law, 3, 34-52.

[30] Konne, B.R. (2014) Inadequate Monitoring and Enforcement in the Nigerian Oil Industry: The Case of Shell and Ogoniland. Cornell International Law Journal, 47, 181-204.

[31] Odje, A.M. (2016) 13\% Derivation, Falling Crude Oil Price and the Constitution. http://www.vanguardngr.com/2016/02/13-derivation-falling-crude-oil-price-and-th e-constitution/

[32] Eboh, M. (2016) Recession: Nigeria's Oil, Gas Reserves Running Out, NNPC Warns.

http://www.vanguardngr.com/2016/10/recession-nigerias-oil-gas-reserves-runningnnpc-warns/

[33] Peterside, C.S. (2014) What Happens in Nigeria When the Oil Wells Run Dry? http://www.resilience.org/stories/2004-11-05/what-happens-nigeria-when-oil-wellsrun-dry

[34] Elebeke, E. (2012) Oil Communities Allege Misappropriation of 13\% Derivation Funds.

http://www.vanguardngr.com/2012/12/oil-communities-allege-misappropriation-of -13-derivation-funds/

[35] Premium Times (2016) Delta, Ondo Oil Communities Demand Control of Deriva- 
tion Money.

http://www.premiumtimesng.com/national-conference/delta-ondo-oil-communitie s-demand-control-derivation-money/

[36] Isa, A. (2013) 13\% Derivation: Edo Community Want Jonathan to Withhold Fund. http://nigeriannewspapers.disnaija.com/peoples-daily-newspaper/13-derivation-edo -communities-want-jonathan-to-withhold-funds/

[37] http://nigerdelta.gov.ng/

[38] Isine, I. (2015) Multibillion Naira Contract Scam Rocks NDDC.

http://www.premiumtimesng.com/news/headlines/188019-multibillion-naira-contr act-scam-rocks-nddc.html

[39] Agbakwuru, J. (2016) Reps C'ttee on NDDC Clash over Location of Projects. http://www.vanguardngr.com/2016/06/reps-cttee-nddc-clash-location-projects/

[40] Idowu, S. (2016) Kachikwu: \$40 bn Spent on Niger Delta in 12 Years without Result. http://www.thisdaylive.com/index.php/2016/08/27/kachikwu-40bn-spent-on-nigerdelta-in-12-years-without-result/

[41] Cap N87 Laws of the Federation of Nigeria (2004).

[42] Premium Times (2016) FG Orders NDDC to Involve Communities in Project Execution.

http://www.premiumtimesng.com/news/top-news/5203-fg-orders-nddc-to-involvecommunities-in-project-execution.html

[43] Enejeta, E. (2016) Buhari Inaugurates Board of Trustees for Implementation of the UNEP Report on Ogoniland.

http://www.financialwatchngr.com/2016/08/04/buhari-inaugurates-board-trustees-i mplementation-unep-report-ogoniland/

[44] Orji, U.J. (2012) An Appraisal of the Legal Frameworks for the Control of Environmental Pollution in Nigeria. Commonwealth Law Bulletin, 38, 321-346.

https://doi.org/10.1080/03050718.2012.674735

[45] Adeyemo. D. and Olu-Adeyemi, L. (2010) Amnesty in a Vacuum: The Unending Insurgency in the Niger Delta of Nigeria. In: Ojakorotu, V. and Gilbert, L.D., Eds., Checkmating the Resurgence of Oil Violence in the Niger Delta of Nigeria, LAP LAMBERT Academic Publishing, Johannesburg, 28-50.

http://www.iags.org/Niger_Delta_book.pdf

[46] Thom-Otuya, B.E.N. and Eremie, V.T. (2011) Amnesty to Niger Delta Militants and Opportunities for Future Peace Missions in Nigeria. International Journal of Business and Social Science, 11, 93-102.

[47] Ebeku, K.S.A. (2008) Niger Delta Oil, Development of the Niger Delta and the New Development Initiative: Some Reflections from a Socio-Legal Perspective. Journal of Asian and African Studies, 43, 399-425. https://doi.org/10.1177/0021909608091974

[48] Vanguard (2016) Militants Blow up another Pipeline in Delta. http://www.vanguardngr.com/2016/09/militants-blow-another-pipeline-delta/ 
Submit or recommend next manuscript to SCIRP and we will provide best service for you:

Accepting pre-submission inquiries through Email, Facebook, LinkedIn, Twitter, etc. A wide selection of journals (inclusive of 9 subjects, more than 200 journals)

Providing 24-hour high-quality service

User-friendly online submission system

Fair and swift peer-review system

Efficient typesetting and proofreading procedure

Display of the result of downloads and visits, as well as the number of cited articles Maximum dissemination of your research work

Submit your manuscript at: http://papersubmission.scirp.org/

Or contact jep@scirp.org 